\title{
Institutional designs of customary fisheries management arrangements in Indonesia, Papua New Guinea, and Mexico
}

\author{
J.E. Cinner ${ }^{\mathrm{a}, *}$, Xavier Basurto ${ }^{\mathrm{b}}$, Pedro Fidelman ${ }^{\mathrm{a}}$, John Kuange ${ }^{\mathrm{c}}$, Rachael Lahari ${ }^{\mathrm{c}}$, Ahmad Mukminin $^{\mathrm{d}}$ \\ a ARC Centre of Excellence for Coral Reef Studies, James Cook University, Townsville, Qld. 4811, Australia \\ b Duke Marine Lab, Duke University, Beaufort, NC 28516, USA \\ ${ }^{\mathrm{C}}$ Wildlife Conservation Society, Papua New Guinea Program, P.O. Box 95, Kavieng, New Ireland Province, Papua New Guinea \\ ${ }^{\mathrm{d}}$ Wildlife Conservation Society, Jalan Burangrang 18, Bogor 16141, Indonesia
}

\section{A R T I C L E I N F O}

\section{Article history:}

Received 21 April 2011

Received in revised form

4 May 2011

Accepted 16 June 2011

Available online 20 July 2011

\section{Keywords:}

Social-ecological system

Institutional design principles

Common property

Customary management

Fisheries

\begin{abstract}
A B S T R A C T
There are considerable efforts by governments, non-governmental organizations (NGOs), and academia to integrate marine conservation initiatives and customary practices, such as taboos that limit resource use. However, these efforts are often pursued without a fundamental understanding of customary institutions. This paper examines the operational rules in use and the presence of institutional design principles in long-enduring and dynamic customary fisheries management institutions in Papua New Guinea, Indonesia, and Mexico. Rather than a "blue print" for devising long-enduring institutions, this study relies on the design principles as a starting point to organize an inquiry into the institutional diversity found in customary governance regimes. Three important trends emerged from this comparative analysis: (1) despite it being notoriously difficult to define boundaries around marine resources, almost 3/4 of the cases in this study had clearly defined boundaries and membership; (2) all of the customary institutions were able to make and change rules, indicating a critical degree of flexibility and autonomy that may be necessary for adaptive management; (3) the customary institutions examined generally lacked key interactions with organizations operating at larger scales, suggesting that they may lack the institutional embeddedness required to confront some common pool resources (CPR) challenges from the broader socioeconomic, institutional and political settings in which they are embedded. Future research will be necessary to better understand how specific institutional designs are related to social and ecological outcomes in commons property institutions.
\end{abstract}

(c) 2011 Elsevier Ltd. All rights reserved.

\section{Introduction}

Throughout the world, common-pool resources (CPR) such as fisheries and forests are being overexploited. CPRs include resources such as coastal fisheries that feature the properties of substractability and excludability. Subtractability refers to situations when harvesting of a resource (e.g., fish) by one person reduces the amount left for others. Excludability refers to the difficulty or high costs associated with excluding other individuals from the benefit stream originated by the resource. Because of these defining characteristics, overexploitation and degradation of CPRs are common.

In many instances, overexploitation of CPRs is viewed as a governance failure. Consequently, increased attention is being paid to understanding the institutions used to manage CPRs. Early studies suggested that unless CPRs were under private or state

\footnotetext{
* Corresponding author. Tel.: +61 747816751; fax: +61 747816722.

E-mail address: joshua.cinner@jcu.edu.au (J.E. Cinner).
}

regimes, resources would be fated to overexploitation (see e.g. [1]). However, research in many field settings across the world has showed that under community-based management regimes users were also capable of devising effective governance rules to prevent overuse [2-5]. In tropical developing nations, community-based management of marine resources has become an increasingly popular paradigm that is based on the notion that local actors are better placed to devise rules to overcome tragedies of the commons [6]. It is clear that community-based management is not a panacea, and significant empirical research is still needed to better understand when it can lead to "improved governance" outcomes and when it might not [7].

In contributing to this empirical inquiry, the concept of institutional "design principles" [3] might provide a useful point of departure for comparative studies. The design principles are broadly construed conditions that can increase the likelihood of sustaining collective action over time, and were derived from the study of well-documented cases of long-enduring CPR regimes [3]. These conditions can, but not necessarily will, provide credible commitments that resource users will maintain and invest in 
their institutions over time. The influence of institutional designs on sustainable governance outcomes are likely affected by configurational interactions with scale dependent factors (see [32]). The so called design principles as defined by Ostrom include: (1) clearly defined boundaries i.e. geographic or institutional such as membership rights; (2) the development and enforcement of rules that limit resource use; (3) congruence between rules and local conditions (i.e. scale and appropriateness); (4) resource users have rights to make, enforce, and change the rules; (5) individuals affected by the rules can participate in changing the rules; (6) resources are monitored; (7) the presence of accountability mechanisms for those monitoring compliance with the rules; (8) sanctions that increase with repeat offenses and in congruence to the severity of such offenses (graduated sanctions); (9) the presence of arenas for discussion and agreement such as conflict resolution; and (10) the degree to which they are nested within other institutions $[3,8]$.

Despite being supported by a large number of empirical studies [9], there is concern that these design principles may not be applicable to a wide range of real life situations or that they may be specific only to certain types of CPRs (see e.g., $[10,11])$. Rather than a "blue print" for devising long-enduring institutions, this study relies on the design principles as a starting point to organize inquiry to describe the institutional diversity found in customary governance regimes [12]. Customary management refers to local norms and practices that regulate the use, access, and transfer of resources [12]. This study is particularly concerned with documenting and examining rules or norms that are generally not formally codified in writing (e.g., laws, statutes, provisions), but that nevertheless, structure action situations. These informal norms are referred to as rules-in-use. Articulating informal institutions as rules-in-use and documenting them across cases, allows scholars to start working towards building a diagnostic approach to community-based governance analysis [13]. Eventually, such diagnostic approaches could help to identify weaknesses/vulnerabilities of community-based management facing demographic changes, technological development, and market integration, among other factors [8].

In this paper, the design principles approach is employed to examine the diversity of customary fisheries management institutions in three well-studied contexts: North Sumatra, Indonesia, New Ireland and Manus Provinces, Papua New Guinea (PNG), and the Northern Gulf of California, Mexico. Main topics of exploration include: (1) the types of operational-level rules employed in the different customary management institutions; (2) whether these customary institutions have key institutional design principles; and (3) the types of linkages institutional entrepreneurs possess at different scales (i.e. cross-scale linkages). This study has important implications for the institutional analyses of contemporary community-based management that draws on elements of customary governance.

\section{Background and study sites}

\subsection{North Sumatra, Indonesia}

Eleven communities were surveyed in the northernmost reaches of Sumatra (the islands of Weh and Aceh) where communities employ a customary management system called Panglima Laot, which literally translates to "Commander of the Sea". Panglima Laot refers to both the system of management and the individual leader who is in charge of developing the rules and regulation appropriate for each fishing ground. The system is formally recognized by the Aceh Provincial Government, which means that the Panglima Laot has de jure authority to determine fishing access rights and fishing gear use, prohibit fishing on religious days, initiate searches for lost fishermen, decide about compensation claims in fishing boat collisions, and arbitrate general disputes. Should a fisherman violate the code of conduct for a given port (or lhok in Achenese), the leader has the authority to banish his boats, apply fines, and ban his attendance at community events and fishing activities.

The system of Panglima Laot has been formally recognized since the 17th century [14]. Historically, Panglima laot leadership was hereditary, but now leaders are selected on the basis of seniority and experience in the field of maritime knowledge. Fishers in each of the 193 lhoks of the province elect an individual who meets with fishers every Friday to adjudicate disputes over marine and coastal resources.

Fishers must pay a fee to join a specific Panglima Laot organization, which can be used as insurance to cover the cost of rescues. Hence, not all fishers are members. Importantly, the traditional role of the Panglima Laot is not to manage fishery resources, per se, but rather to create social order by minimizing and resolving conflicts among fishers [14]. Nevertheless informal interviews with Panglima Laot leaders reveal that some fishing restrictions are seen as a way to sustain fishery stocks for future use. The types of fishing restrictions vary greatly among different lhoks. On Weh Island, cyanide and blast fishing are prohibited in all lhoks while various sanctions on the use of certain types of nets, speargun, and rudimentary underwater breathing apparatus called "hookahs" are present in certain lhoks.

\subsection{Muluk and Ahus villages, Papua New Guinea}

In many parts of Melanesia, there is a wide range of customary practices that limit access to specific fishing grounds, species, gear, and the times that people can fish [15-17]. These practices are generally embedded in a system of customary marine tenure, whereby complex use rights determine whether and how individuals and communities can access marine resources [16,18-20]. In PNG, the national government provides legal recognition of rights to customary management by local communities, making these rights de jure [21].

The Muluk community, on the eastern side of Karkar Island, claims exclusive-use rights over reefs adjacent to their village. In Muluk, different reef patches are owned by separate clans, through well-recognized customary tenure institutions that are pervasive through much of PNG. In addition to customary tenure arrangements, there is also a dynamic system of closing certain fishing grounds. Formerly, whenever the three main clan chiefs noticed that fish catch was declining, they decided to close the majority of the fishing ground (approximately 58 ha of reef adjacent to the village) for 1-2 years [22]. The explicitly stated reason for the closures was that fish "would become easier to catch" after some period of closure, particularly for spearfishing [23]. By periodically closing the resource to extractive activities, it was thought that reef fishes would become more "tame," thereby allowing fishers to more effectively catch fish. The decision to close reefs was previously reached through a consensus between the three clanchiefs. The reef closure in Muluk generally occurred 2-3 times within a 10-year span. Previous research has detailed the social conditions and ecological impacts of this system [22,24,25]. In recent years, the form of management has changed. Following research in 2001, a portion of the reef belonging to one clan remained closed for all but two weeks in a seven year period. In 2009 , this was opened at the same time that another patch of reef owned by the same clan was closed. Although the system is dynamic, it has been in operation for as long as living memory.

Marine resources at Ahus and other island communities on the north coast of Manus are governed by an intricate system of 
customary rights that determine whether and how specific individuals, families, clans, and villages can access particular reef areas, target specific species, and engage in specific harvesting methods [19,26-30]. The fishing grounds under Ahus' customary tenure encompass 550 ha of reef lagoon. Customary taboos (tambu) restrict fishing in six small areas totaling 33.2 ha, or 6\% of Ahus' reef area. Decisions to implement restrictions or harvest within each tambu area are the responsibility of the kinship group with control over that specific reef area. These tambu areas have been operating for as long as living memory in the village. In addition to the restricted (tambu) areas, there are also specific ownership rights to species and gears. Certain kin groups have rights to harvest specific species (e.g., turtle), while other kin groups have exclusive right to use specific fishing gears. People from one kin groups have to get permission to target species or use gear that is customarily owned by other groups.

\subsection{The Seri pen shell fishery in the Gulf of California, Mexico}

The Seri or Comcáac people are a distinct cultural group of seafaring, ex-nomadic hunters and gatherers that have lived in the Midriff Island Region of the Gulf of California, Mexico for thousands of years [31]. They stand out among other small-scale fishing communities in the Gulf of California, Mexico, for their ability to control access to their pen shell fishing resources and avoid overexploitation [32]. The Comcáac harvest pen shellssessile bivalve mollusks (mostly Atrina tuberculosa and Pinna rugosa)-that command high market prices and are fished by divers that unbury them using hookahs [33].

Like most small-scale fisheries in Mexico, the pen shell fishery, is de jure regulated by the federal government through a fishing licensing/permitting system. In practice, there is no monitoring or enforcement by the federal authorities and the Comcáac have devised an informal common-property regime to govern their fishery. Its emergence was enabled in the 1970s, when the Mexican government formally granted the Comcáac land tenure and a large multi-species fishing concession [34]. While their fishing concession encompasses the entire coast surrounding Tiburon Island, Mexico's largest, the Comcáac are only able to effectively monitor and enforce access to the area encompassing the Infiernillo Channel [35].

Access to this area by outside fishers is in high demand, given that it yields the most abundant catches of pen shells in the region [36]. In response, the Comcáac have designed a number of rules-in-use to control access to outsiders. For instance, one rule dictates that for every non-Comcáac fishing crew to become an authorized entrant to the Channel, a member of the Comcáac community must be hired as part of the fishing crew. Given that it is customary to share the catch among all the members of the fishing crew, this rule diminishes the economic incentive of outsiders to come into the Infiernillo Channel. This rule also provides community members with a source of income and a low cost monitoring mechanism of outsider activities within the Channel. Other rules determine spatial limits to fishers or entry fees.

Throughout the thirty years this commercial fishery has operated, the Comcáac do not seem to have ceased to experiment with rules in an attempt to balance the benefits and costs that the presence of outsiders generates to the community-which themselves shift overtime. In general, the Comcáac use a wide range of techniques to monitor and enforce agreements with outsiders, varying from verbal reprimands and other forms of public shaming to the threat of confiscation of fishing gear [37]. Based in the conflictive history that the Comcáac have had with their Mexican neighbors and the Spaniards before them, the Comcáac's efforts to control access to their fisheries are better interpreted as acts of self-determination against a new form of invasion to their homeland, rather than as strategies to avoid overexploitation of their fishing resources.

The maintenance of the Comcáac pen shell institution has been facilitated by a number of biophysical characteristics of the social-ecological system, that likely help buffer spikes in fishing effort when monitoring and enforcement fails to effectively control access $[36,38]$. For instance, the presence of extensive meadows of eelgrass Zostera marina covering up to $22 \%$ of the Channel's bottom for up to eight months of the year [39], prevent harvesting the pen shells that inhabit those areas, likely having positive effects for the recovery of the fishing stock. Other pen shell-specific characteristics include a continuous reproductive cycle [40-42], a spatial one to one sex ratio relationship $[38,42,43]$, a rapid growth and sexual maturation that allows most of the pen shells to spawn before being harvested [38], and the lack of sexual dimorphism that could drive the harvest of one sex over the other. All together, they make the species less susceptible to sudden perturbations and rapid overexploitation.

\section{Methods}

Socioeconomic studies were conducted in 20 villages across Papua New Guinea, Indonesia, and Mexico as part of ongoing research collaborations with local communities between 2000 and 2010. To examine and document rules-in-use that had not formally been codified in writing, we used a purposive case selection strategy to choose cases of fishing communities with a long place-based history, for which there was first hand access to primary data. This resulted in a total of 15 different reef/fisheries governance institutions spread over 20 communities (Table 1). Some institutions, such as the Iue Muelee Panglima Laot in Indonesia, comprised three separate villages, others like the Seri in Mexico comprised one village, and yet at Ahus Island, Papua New Guinea, two separate sets of rules-in-use within the same community were identified and studied. The data primarily come from field research conducted over 2001-2002 and 2008-2009 in Papua New Guinea and Indonesia and at different time periods between 2000 and 2010 in Mexico. In each community, at least one key informant, community leaders, and/or traditional leader of the various customary management institutions were interviewed in the local or national language using semistructured interviews to elicit conversations about aspects of

Table 1

List of study sites and institutions. PL= Panglima Laot.

\begin{tabular}{lll}
\hline Country & Community & Institution \\
\hline Indonesia & Anoi Itam & Anoi Itam PL \\
Indonesia & Balohan & Balohan PL \\
Indonesia & BateeShok & Pria Laot PL \\
Indonesia & Buerawang & Buerawang PL \\
Indonesia & Iboih & Iboih PL \\
Indonesia & IeMeulee & Ieu Meulee PL \\
Indonesia & KotaAtas & Ieu Meulee PL \\
Indonesia & Ujong Kareung & Ieu Meulee PL \\
Indonesia & Jaboi & Jaboi PL \\
Indonesia & Keuneukai & Keuneukai PL \\
Indonesia & Lampuyang & Pulo Aceh PL \\
Indonesia & Lamteng & Pulo Aceh PL \\
Indonesia & Paloh & Pulo Aceh PL \\
Indonesia & Kota Bawah Barat & Pasiran PL \\
Indonesia & Kota Bawah Timur & Pasiran PL \\
Indonesia & Krueng Raya & Pasiran PL \\
Indonesia & Paya & Paya PL \\
Mexico & Seri or Comcaác & Pen shell fishery \\
Papua New Guinea & Muluk & Muluk tambu \\
Papua New Guinea & Ahus Island & Ahus east tambu \\
& & Ahus west tambu \\
\hline & & \\
\hline & &
\end{tabular}


Table 2

Description of the indicators examined at each study site.

\begin{tabular}{|c|c|}
\hline Indicator & Description \\
\hline Operational rules-in-use & $\begin{array}{l}\text { Whether there were formal or informally recognized rules being practiced to limit fishing activities. Recorded separately for restrictions } \\
\text { on area, time, gear, and species. }\end{array}$ \\
\hline $\begin{array}{l}\text { Clearly defined } \\
\text { boundaries }\end{array}$ & $\begin{array}{l}\text { Whether boundaries are easily recognized (based on a } 3 \text { point scale where } 1=\text { difficult to recognize, } 3=\text { very easy to recognize and were } \\
\text { never confused). }\end{array}$ \\
\hline $\begin{array}{l}\text { Clearly defined } \\
\text { membership }\end{array}$ & Whether there is ever confusion about who belongs to the social group that makes up the institution $(\mathrm{y} / \mathrm{n})$. \\
\hline Rights to organize & $\begin{array}{l}\text { Resource users have a de facto or de jure minimal level of autonomy from higher level authorities to design and change rules, and do so } \\
\text { through formal or informal mechanisms }(\mathrm{y} / \mathrm{n}) \text {. }\end{array}$ \\
\hline Graduated sanctions & $\begin{array}{l}\text { Whether sanctions increase with numerous offenses or the severity of the offense }(y / n) \text {. This was recorded separately for each operational } \\
\text { rule. }\end{array}$ \\
\hline $\begin{array}{l}\text { Conflict resolution } \\
\text { mechanisms }\end{array}$ & $\begin{array}{l}\text { Whether mechanisms exist to resolve conflicts between resource users, and the degree to which it is effective at resolution based on a six } \\
\text { point ordinal scale where }(0=\text { no mechanisms exists, } 1=\text { exists but completely ineffective, } 5=\text { always effective). }\end{array}$ \\
\hline Nested enterprises & $\begin{array}{l}\text { The frequency of contacts the organization leader has with members of other institutions: (a) community leaders; (b) district officials; } \\
\text { (c) local officials; (d) conservation/management officials; (e) donors; (f) financial institutions; (g) NGO/scientific organizations. Frequency } \\
\text { for each linkage measured as } 1=\text { never, } 2=\text { infrequently ( }<1 \text { time/year), } 3=\text { regularly ( } \geq 1 \text { time/year). }\end{array}$ \\
\hline
\end{tabular}

institutional designs, operational rules, and linkages with external institutions (Table 2). The Mexico data also relied on previously published literature. Responses from the different types of informants were triangulated and informed by participant observation and expert opinion from the long history of working in these areas.

\section{Results}

\subsection{Operational rules}

Customary institutions used a range of operational rules to limit use of marine resources. The diversity of operational rules could be typified as governing the spatial extent of harvesting activities (i.e. gear), temporality, and customary marine tenure (Table 3). Based on this classification, the least used restriction among the cases analyzed was spatial, while gear, and temporal restrictions on harvesting (i.e. closed areas) were very common.

Five of the Panglima Laot systems only restricted fishing on Fridays, whereas the other six Indonesian sites restricted destructive fishing gears such as cyanide, blast fishing, and the use of nets in reef areas. In Papua New Guinea, all sites had similar types of restrictions, with areas of reef that were closed to fishing, controls on who could use certain gears (typically based on ownership rights and initiations that limited participation in certain types of fishing practices for young males until a ceremony had been undertaken), and the exclusion of 'outsiders' through customary marine tenure. The level of surveillance (i.e. monitoring and enforcement activities conducted by the institutional members themselves, NGOs, government agencies) varied considerably across the institutions, and almost of the customary institutions half had no surveillance. Only four sites had frequent surveillance (Beurawang, Pasiran, Muluk, and Ahus west). Likewise, only the Comcáac, Jaboi, Ieu Meulee, and Iboh had occasional surveillance.

Interestingly, not all rules were customary in origin. Respondents noted that the sources of the rules varied considerably. For example, in Indonesia, none of the area-based restrictions were customary in nature, but instead were government-operated marine protected areas. Additionally, many of the Indonesian Panglima Laot leaders felt that the sources of the gear restrictions were combinations of customary law, national government, and community partnerships with NGOs.

\subsection{Institutional design principles}

A number of the institutional design principles thought to be important in the success of long-enduring common property institutions were present at the study sites (Table 4). Boundaries and membership were generally clearly defined and rarely confused (Table 4). Only Balohan and Pulo Aceh Panglima Laots ever had their boundaries confused. Membership criteria varied from institution to institution, with some, such as Panglima Laot, requiring fees, and others being based on village residence and/ or clan affiliation (e.g., Comcáac and Ahus). Membership had been confused in Balohan, Pasiran, Pria Laot, and Ahus west. In the Ahus west area, for example, a clan leader noted that intermarriage and resultant resource use rights were occasionally mistaken. Importantly, in all cases, those able to change the rules were either institutional or community members. All sites had de facto rights to make and change rules. For example, in Pulau Weh, fishing grounds are open to people from any village, as long as they follow the rules of the local Panglima Laots. However, people from other villages have no say in changing these rules.

Graduated sanctions were common in most institutions (Table 4). In some institutions the application of graduated sanctions varied depending on the operational rule used. Eleven of the 20 institutions reported a high degree of success in resolving conflicts (Table 4). Pulo Aceh and Ahus reported that few conflicts are resolved, while the Comcáac reported that about half of the conflicts are resolved. All other sites reported that most or all of the conflicts are resolved. For instance, conflicts among the Comcáac are often dealt with through discussions between family members of those implicated. When agreements for restitution are reached they often include payment in monetary currency or in the form of goods. But in many instances members of the family cannot reach an agreement and the conflict can linger over a long time affecting the fluidity of the interactions between families.

The frequency of interactions that a local entrepreneur or leader from a customary institution had with other entrepreneurs and institutions located at different levels of organization/decision-making was examined. These interactions were operationalized as indicators of institutional linkages and nestedness (Table 5). Nestedness refers to the degree to which the institution has connections to and is embedded in other levels of decisionmaking, governance, and resource allocation. No community had linkages with the full suite of partners (community leader, local official, district official, conservation or management officer, donor, financial institution, NGO, or scientific organization, Table 5). Most organizational leaders lacked linkages with donors (74\%), financial institutions (60\%), and NGOs or scientific organizations (80\%). Most organizational leaders had regular contact with the elected community officials, and occasional contacts with local and district officials. 
Table 3

Operational rules of the customary institutions. PL=Panglima Laot.

\begin{tabular}{|c|c|c|c|c|c|c|}
\hline \multirow[t]{2}{*}{ Institution } & \multirow[t]{2}{*}{ Diversity of operational rules } & \multicolumn{4}{|c|}{ Types of operational rules } & \multirow[t]{2}{*}{ Surveillance } \\
\hline & & Spatial & Gear & Temporal & Tenure & \\
\hline Anoi Itam PL & $\begin{array}{l}\text { Closed area } \\
\text { No net fishing over reef } \\
\text { No fishing on Fridays }\end{array}$ & Yes & Yes & Yes & No & Absent \\
\hline Balohan PL & No fishing on Fridays & No & No & Yes & No & Absent \\
\hline Beurawang PL & $\begin{array}{l}\text { No cyanide } \\
\text { No blast fishing } \\
\text { No fishing on Fridays }\end{array}$ & No & Yes & Yes & No & Often \\
\hline Iboih PL & $\begin{array}{l}\text { Closed area } \\
\text { No net fishing over reef } \\
\text { No cyanide } \\
\text { No blast fishing } \\
\text { No hookah diving } \\
\text { No spear fishing }\end{array}$ & Yes & Yes & Yes & No & Occasional \\
\hline Ieu Meulee PL & $\begin{array}{l}\text { No net fishing over reef } \\
\text { No cyanide } \\
\text { No blast fishing } \\
\text { No hookah diving } \\
\text { No fishing on Fridays }\end{array}$ & No & Yes & Yes & No & Occasional \\
\hline Jaboi PL & $\begin{array}{l}\text { No net fishing over reef } \\
\text { No fishing on Fridays }\end{array}$ & No & Yes & Yes & No & Occasional \\
\hline Keuneukai PL & $\begin{array}{l}\text { No net fishing over reef } \\
\text { No fishing on Fridays }\end{array}$ & No & Yes & Yes & No & Never \\
\hline Pulo Aceh PL & No fishing on Fridays & No & No & Yes & No & Never \\
\hline Pasiran PL & No fishing on Fridays & No & No & Yes & No & Often \\
\hline Paya PL & No fishing on Fridays & No & No & Yes & No & Never \\
\hline Pria Laot PL & No fishing on Fridays & No & No & Yes & No & Never \\
\hline Seri pen shell fishery & $\begin{array}{l}\text { Closed area } \\
\text { No hookah diving on sand bars }\end{array}$ & Yes & Yes & No & Yes & Occasional \\
\hline Muluk community & $\begin{array}{l}\text { Closed area } \\
\text { User rights regulating who can } \\
\text { use specific gears }\end{array}$ & Yes & Yes & No & Yes & Often \\
\hline Ahus west tambu & $\begin{array}{l}\text { Closed area } \\
\text { User rights regulating who can } \\
\text { use specific gears }\end{array}$ & Yes & Yes & No & Yes & Often \\
\hline Ahus east tambu & $\begin{array}{l}\text { Closed area } \\
\text { User rights regulating who can } \\
\text { use specific gears }\end{array}$ & Yes & Yes & No & Yes & Never \\
\hline
\end{tabular}

\section{Discussion}

\subsection{Operational rules}

This study found considerable diversity of rules and the presence of a number of the design principles hypothesized to be important for long-enduring natural resources governance institutions. In terms of operational rules, the most common in the study sites was no fishing on Friday, (the Muslim Sabbath). This was obviously influenced by the disproportional number of Indonesian study sites. After temporal restrictions, sites with gear restrictions and surveillance were found most often in the dataset. Of course, the purposive sampling methodology employed for site selection prevent broader inferences from being made about the prevalence of specific types of operational rules in customary management systems in other locations.

There was a range of different types of closure systems. In Ahus Island, PNG and the Seri in Mexico had permanent closures based on gear type used. Muluk village in PNG employed periodic closures. In Indonesia, there were no customary closures, however there were several government-operated marine protected areas. Importantly, this heterogeneity in operational rules has implications for the local ecology. For example, in Aceh, Lhoks with rules that restrict the most destructive types of fishing nets had up to six times higher fish biomass compared to adjacent fishing areas where nets are allowed (Campbell et al., unpublished). In addition, hard-coral cover was up to six times higher at sites where more types of fishing gears were prohibited.

\subsection{Institutional design principles}

There has been increasing interest in understanding the architecture of institutions and how this may influence resource users' ability to successfully overcome CPR dilemmas [3,9]. This is the first paper to systematically examine the presence of design principles in customary fisheries management institutions. In this study, the 17 existing cases that have previously examined design principles in fisheries [9] were nearly doubled. Three important trends emerged from this comparative analysis: (1) despite it being notoriously difficult to define boundaries around marine resources, almost 3/4 of the cases had clearly defined boundaries and membership; (2) all of the customary institutions were able to make and change rules, indicating a critical degree of flexibility and autonomy that may be necessary for adaptive management; 
Table 4

Institutional design principles. $\mathrm{PL}=$ Panglima Laot; $\mathrm{Y}=\mathrm{yes}, \mathrm{N}=$ no; operational rules: $\mathrm{A}=\mathrm{area} /$ spatial restrictions, $\mathrm{G}=$ gear restrictions, $\mathrm{T}=$ temporal restrictions.

\begin{tabular}{|c|c|c|c|c|c|c|c|}
\hline Country & Institution & $\begin{array}{l}\text { Boundary ever } \\
\text { confused? }\end{array}$ & $\begin{array}{l}\text { Membership } \\
\text { ever confused? }\end{array}$ & $\begin{array}{l}\text { Resource users } \\
\text { can make and } \\
\text { change rules }\end{array}$ & $\begin{array}{l}\text { Resource users } \\
\text { can change rule }\end{array}$ & $\begin{array}{l}\text { Graduated } \\
\text { sanctions }\end{array}$ & $\begin{array}{l}\text { Success of conflict } \\
\text { resolution } \\
\text { mechanisms }^{\text {a }}\end{array}$ \\
\hline Indo & Anoi Itam PL & $\mathrm{N}$ & $\mathrm{N}$ & $\mathrm{Y}$ & $\mathrm{Y}$ & $\mathrm{A}=\mathrm{N}, \mathrm{G}=\mathrm{Y}, \mathrm{T}=\mathrm{Y}$ & 4 \\
\hline Indo & Balohan PL & $\mathrm{Y}$ & $\mathrm{Y}$ & $\mathrm{Y}$ & $\mathrm{Y}$ & $\mathrm{Y}$ & 5 \\
\hline Indo & Beurawang PL & $\mathrm{N}$ & $\mathrm{N}$ & $\mathrm{Y}$ & $\mathrm{Y}$ & Do not know & 5 \\
\hline Indo & Iboih PL & $\mathrm{N}$ & $\mathrm{N}$ & $\mathrm{Y}$ & $\mathrm{Y}$ & $\mathrm{A}=\mathrm{N}$ & 4 \\
\hline Indo & Ieu Meulee PL & $\mathrm{N}$ & $\mathrm{N}$ & $\mathrm{Y}$ & $\mathrm{Y}$ & $\begin{array}{l}\mathrm{G}=\mathrm{Y}, \mathrm{G}=\mathrm{Y} \\
\mathrm{G}=\mathrm{N}, \mathrm{G}=\mathrm{Y}\end{array}$ & 5 \\
\hline Indo & Jaboi PL & $\mathrm{Y}$ & $\mathrm{N}$ & $\mathrm{Y}$ & $\mathrm{Y}$ & $\mathrm{Y}$ & 5 \\
\hline Indo & Keuneukai PL & $\mathrm{N}$ & $\mathrm{N}$ & $\mathrm{Y}$ & $\mathrm{Y}$ & $\mathrm{Y}$ & 5 \\
\hline Indo & Pulo Aceh PL & $\mathrm{Y}$ & $\mathrm{N}$ & $\mathrm{Y}$ & Y & Do not know & 2 \\
\hline Indo & Pasiran PL & $\mathrm{N}$ & $\mathrm{Y}$ & $\mathrm{Y}$ & $\mathrm{Y}$ & $\mathrm{Y}$ & 5 \\
\hline Indo & Paya PL & $\mathrm{N}$ & $\mathrm{N}$ & $\mathrm{Y}$ & $\mathrm{Y}$ & $\mathrm{Y}$ & 5 \\
\hline Indo & Pria Laot PL & $\mathrm{N}$ & $\mathrm{Y}$ & $\mathrm{Y}$ & $\mathrm{Y}$ & $\mathrm{Y}$ & 5 \\
\hline Mexico & $\begin{array}{l}\text { Seri pen shell } \\
\text { fishery }\end{array}$ & $\mathrm{N}$ & $\mathrm{N}$ & $\mathrm{Y}$ & $\mathrm{Y}$ & $\mathrm{Y}$ & 3 \\
\hline PNG & $\begin{array}{l}\text { Muluk } \\
\text { community }\end{array}$ & $\mathrm{N}$ & $\mathrm{N}$ & $\mathrm{Y}$ & $\mathrm{Y}$ & $\mathrm{N}$ & 4 \\
\hline PNG & $\begin{array}{l}\text { Ahus west } \\
\text { tambu }\end{array}$ & $\mathrm{N}$ & $\mathrm{Y}$ & $\mathrm{Y}$ & $\mathrm{Y}$ & $\mathrm{Y}$ & 2 \\
\hline PNG & Ahus east tambu & $\mathrm{Y}$ & $\mathrm{N}$ & $\mathrm{Y}$ & $\mathrm{Y}$ & $\mathrm{Y}$ & 2 \\
\hline
\end{tabular}

${ }^{\text {a }}$ Scaled from $0-5.5=$ all conflicts get resolved in a reasonable time frame, $4=$ most conflicts get resolved, $3=$ about half the conflicts get resolved, $2=$ few conflicts get resolved, 1 is mechanisms exists but is unsuccessful at resolving conflicts, $0=$ no mechanisms exists.

Table 5

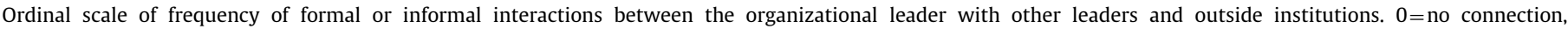
$1=$ occasional contact ( $<1$ time/year), $2=$ regular contact ( $\geq 1$ time/year).

\begin{tabular}{|c|c|c|c|c|c|c|c|c|}
\hline Country & Institution & $\begin{array}{l}\text { Comm. } \\
\text { leader }\end{array}$ & $\begin{array}{l}\text { District } \\
\text { official }\end{array}$ & $\begin{array}{l}\text { Local } \\
\text { official }\end{array}$ & $\begin{array}{l}\text { Conservation or } \\
\text { management } \\
\text { officer }\end{array}$ & Donor & $\begin{array}{l}\text { Financial } \\
\text { institution }\end{array}$ & $\begin{array}{l}\text { NGO or } \\
\text { scientific } \\
\text { org. }\end{array}$ \\
\hline Indo & Anoi Itam PL & 2 & 1 & 1 & 2 & 1 & 0 & 0 \\
\hline Indo & Balohan PL & 1 & 1 & 1 & 0 & 1 & 1 & 1 \\
\hline Indo & Beurawang PL & 1 & 1 & 0 & 0 & 0 & 0 & 0 \\
\hline Indo & Iboih PL & 2 & 2 & 1 & 2 & 1 & 2 & 1 \\
\hline Indo & Ieu Meulee PL & 2 & 2 & 2 & 2 & 0 & 1 & 2 \\
\hline Indo & Jaboi PL & 1 & 1 & 0 & 1 & 0 & 1 & 0 \\
\hline Indo & Keuneukai PL & 2 & 2 & 1 & 2 & 1 & 1 & 0 \\
\hline Indo & Pulo Aceh PL & 2 & 1 & 0 & 0 & 0 & 0 & 0 \\
\hline Indo & Pasiran PL & 1 & 1 & 1 & 0 & 0 & 0 & 0 \\
\hline Indo & Paya PL & 2 & 1 & 1 & 1 & 0 & 0 & 0 \\
\hline Indo & Pria Laot PL & 2 & 1 & 1 & 1 & 0 & 0 & 0 \\
\hline Mexico & Seri pen shell fishery & 2 & 0 & 0 & 0 & 0 & 0 & 0 \\
\hline PNG & Muluk community & 2 & 2 & 1 & 0 & 0 & 0 & 0 \\
\hline PNG & Ahus west tambu & 2 & 1 & 0 & 1 & 0 & 1 & 0 \\
\hline PNG & Ahus east tambu & 1 & 0 & 0 & 1 & 0 & 0 & 0 \\
\hline
\end{tabular}

(3) the customary institutions examined generally lacked key interactions with organizations operating at larger scales, suggesting that customary institutions may lack the institutional embeddedness required to confront some CPR challenges from the broader socioeconomic, institutional, and political settings in which they operate in.

In this study, $73 \%$ of the sites had clearly defined boundaries and/or membership (although not all sites had both, Table 4). This is slightly higher than the $62 \%$ of cases identified in a global review of all types of commons institutions (forestry, fishery, pastoral, irrigation, etc.) that had clearly defined membership, and about the same as the $72 \%$ of cases that had clearly defined boundaries [9]. For the fisheries-specific cases in studies in the global review, $72 \%$ reported clearly defined membership, and nine out of ten cases reported the presence of resource boundaries (M. Cox, Pers. Com). However, these figures can be slightly misleading because a full $50 \%$ of the fishery-related cases did not report sufficiently on resource boundaries, which could be interpreted as absence of this design principle (M. Cox. Pers. Com.). This suggests that the customary institutions studied have a slightly higher than average clarity of membership, despite their informal nature. Importantly, boundaries in fisheries systems can be extremely difficult to define, yet the same proportion of customary fisheries management systems studied had clear boundaries as observed in diverse systems like forestry, pastoral, and irrigation. A critical question is why do the customary institutions studied have boundaries and membership that are rarely confused, despite the marine resource boundaries being difficult to define by their very nature (i.e. hard to place boundary markers such as a fence, flat and reflective surface, etc.)? One hypothesis is that boundaries and membership are clearly defined in part because these institutions cover a relatively small geographic area with small populations. Customary ownership of resources can, however, be contested, particularly when intermarriage can provide some use rights and blur ownership boundaries $[18,19,45,46]$.

The second key trend observed in this study was that all sites were able to develop and change the operational rules. Indeed, some institutions were observed to have dynamic rules between field research expeditions. For example, the marine closure system at Muluk village changed from being a larger closure 
managed by all three of the main clans in 2002 to being a smaller closure controlled by a single clan in 2009. Critically, this type of autonomy and flexibility to adapt and change rules based on social or economic conditions is considered a critical component of the response systems necessary for adaptive management $[47,48]$. Adaptive management recognizes the need to change strategies based on emerging trends in social, economic, ecological, and environmental systems and is thought to be critical to the success of some types of common property management systems, including fisheries $[48,49]$. Adaptive management systems need to have both monitoring and response stages [48], which have been shown to be present in customary fisheries management institutions [22,47]. For example, Cinner et al. [22] developed a conceptual model of the phases in which communities use customary taboos as adaptive management. These were: (1) placing the taboo, which requires a flexible governance structure; (2) observing the taboo, which may be facilitated by key design principles that help to provide credible commitments that people will follow the rules; (3) evaluating the system, requiring traditional ecological knowledge to observe and make sense of environmental and social conditions; and (4) lifting the taboo.

Even though all sites had the response flexibility to make and change rules, people affected by the rules often could not necessarily participate in changing them if they were not affiliated with the institution. For example in Aceh, people had to obey rules for each specific fishing ground but could only participate in changing the rules relating to the fishing ground near their village (i.e. in the Panglima Laot to which they belonged). This may contrast from broader participatory decision-making processes in places like Australia, where the rezoning of the Great Barrier Reef Marine Park involved 30,000 comments from the general public [50]. In the latter example, however, it was difficult to discern the influence of these consultations on the actual decision-making.

The third key trend observed in this study was that customary institutions generally lacked linkages to donors, financial institutions, and to a lesser degree $\mathrm{NGO} /$ scientific organizations and conservation/management officers. Critically, this suggests that these customary institutions may not be effectively embedded in institutional settings at larger scales, which may hamper their capacity to draw upon resources or support (e.g., enforcement and scientific insights) from those scales. Cross-scale linkages can provide support by larger institutional contexts, which are thought to be critical to the success of adaptive fisheries management [51]. CPRs are increasingly recognized as multilevel systems [52,53], even more so when CPRs such as fisheries are affected by contemporary global drivers [54,55]. Because local level rules are not sufficient to deal with CPR problems in a multilevel world, a multilevel approach is essential [52,56]. Marine resources in particular need to be managed simultaneously at multiple governance levels, which in turn require establishing links across scales [56]. Such links may facilitate learning and adaptation by: (1) connecting local (i.e. community-based) management with regional and national government-level management; (2) linking key components of scientific and traditional management systems [20]; (3) promoting exchange of knowledge and information; and (4) fostering dialog and collaboration around goals and outcomes [53].

\subsection{Critiques, caveats, and future directions}

Some design principles proved difficult to assess given the methodology employed in the field study. In some cases, inferences can be made based on the data collected. For example, congruence between rules and local conditions, which was not explicitly assessed in this study, may be inferred from data on the ability of institutional members to make and change rules. Because rules in the institutions analyzed are made and changed by the members who are believed to have a good knowledge of the local conditions, it is suggested that these rules are to a large extent congruent with local customs, livelihood strategies and resource conditions.

In other cases, it is not possible to systematically assess some of the design principles, such as monitoring and accountability mechanisms for those monitoring rules. Monitoring is key for rule enforcement and it is important that monitors are accountable to resource users or are resource users themselves [8]. Future research on monitoring and accountability may prove beneficial to further improving the understanding of customary fisheries institutions. Likewise, important next steps are to better understand how specific institutional designs are related to social and ecological outcomes in CPR institutions.

\section{Acknowledgments}

This research was funded by the Australian Research Council, the National Geographic Society (Grant no. 8506-08) and the Christensen Fund. Thanks to K. Holmes for constructive comments on an earlier version of the manuscript and to the communities that participated in this study.

\section{References}

[1] Hardin G. The tragedy of the commons. Science 1968;162:1243-8.

[2] Bromley DW. Making the commons work: theory, practice and policy. San Francisco: Institute for Contemporary Studies; 1992. p. 339.

[3] Ostrom E. Governing the commons: the evolution of institutions for collective action. Cambridge, United Kingdom: Cambridge University Press; 1990.

[4] Pinkerton E. Co-operative management of local fisheries new directions for improved management and community development. Vancouver, BC: University of British Columbia Press; 1989.

[5] Berkes F. Cooperation from the perspective of human ecology. In: Berkes F, editor. Common property resources: ecology and community-based sustainable development. London: Belhaven Press; 1989. p. 70-88.

[6] Jones C, Horwich R. Constructive criticism of community-based conservation. Conserv Biol 2005;19:990-1.

[7] Mansuri G, Rao V. Community-based and -driven development: a critical review. World Bank Res Obser 2004;19:1-39.

[8] Ostrom E. Understanding institutional diversity. Princeton: Princeton University Press; 2005.

[9] Cox M, Arnold G, Tomás SV. A review of design principles for communitybased natural resource management. Ecol Soc 2010;15(4):38.

[10] Steins NA, Edwards VM. Collective action in common-pool resource management: the contribution of a social constructivist perspective to existing theory. Soc Nat Resour 1999;12:539-57.

[11] Quinn $\mathrm{CH}$, Huby M, Kiwasila H, Lovett JC. Design principles and common pool resource management: an institutional approach to evaluating community management in semi-arid Tanzania. J Environ Manage 2007;84:100-13.

[12] Cinner JE, Aswani S. Integrating customary management into marine conservation. Biol Conserv 2007;140:201-16.

[13] Ostrom E, Cox M. Moving beyond panaceas: a multi-tiered diagnostic approach for social-ecological analysis. Environ Conserv 2010;37:1-13.

[14] Nurdin M, Efendi Basri. Peranan hukom adat laot dalam pengelolaan sumberdaya pesisir menurut undang-undang nomor 22 tahun 1999 dan konvensi hukum laut 1982. Suatu penelitian di kabupaten aceh besar: laporan penelitian [dosen muda]. Banda Aceh: Fakultas Hukum Universitas Syiahkuala; 2003.

[15] Colding J, Folke C. Social taboos: 'invisible' systems of local resource management and biological conservation. Ecol Appl 2001;11:584-600.

[16] Hviding E. Guardians of the marovo lagoon: practice, place, and politics in maritime melanesia. Honolulu: University Press of Hawai'i; 1996.

[17] Colding J, Folke C. The relations among threatened species, their protection, and taboos. Conserv Ecol 1997;1:6.

[18] Carrier J, Carrier A. Profitless property: marine ownership and access to wealth on Ponam Island, Manus Province. Ethnology 1983;22:133-51.

[19] Carrier J. Marine tenure and conservation in Papua New Guinea. In: McCay B, Acheson J, editors. The question of the commons: the culture and ecology of common resources. Tucson: The University of Arizona Press; 1987. p. 143-67.

[20] Aswani S, Hamilton RJ. Integrating indigenous ecological knowledge and customary sea tenure with marine science and social science for conservation 
of bumphead parrotfish (Bolbometopon muricatum) in the Roviana Lagoon, Solomon Islands. Environ Conserv 2004;31:69-83.

[21] Hyndman D. Sea tenure and the management of living marine resources in Papua New Guinea. Pac Stud 1993;16:99-114.

[22] Cinner J, Marnane M, McClanahan T, Almany G. Periodic closures as adaptive coral reef management in the Indo-Pacific. Ecol Soc 2006;11(1).

[23] Feary DA, Cinner JE, Graham NAJ, Januchowski-Hartley FA. Effects of customary marine closures on fish behavior, spear-fishing success, and underwater visual surveys. Conserv Biol 2011;25:341-9.

[24] Cinner JE. Designing marine reserves to reflect local socioeconomic conditions: lessons from long-enduring customary management systems. Coral Reefs 2007;26:1035-45.

[25] McClanahan T, Marnane M, Cinner J, Kiene W. A comparison of marine protected areas and alternative approaches to coral reef conservation. Curr Biol 2006;16:1408-13.

[26] Carrier J. Conservation and conceptions of the environment: a Manus Province case study. In: Morauta L, Pernetta J, Heaney, editors. Traditional conservation in Papua New Guinea: implications for today. Boroko, Papua New Guinea: Institute of Applied Social and Economic Research; 1982. p. 39-43.

[27] Carrier J, Carrier A. Wage trade, and exchange in Melanesia: a Manus society in the modern state. Berkeley: University of California Press; 1989.

[28] Carrier J, Carrier A. Marine tenure and economic reward on Ponham Island, Manus Province. In: Cordell J, editor. A sea of small boats. Cambridge, USA: Cultural Survival, Inc.; 1989. p. 60-93.

[29] Cinner J, Marnane M, McClanahan T. Conservation and community benefits from traditional coral reef management at Ahus Island, Papua New Guinea. Conserv Biol 2005;19:1714-23.

[30] Cinner JE, Marnane MJ, McClanahan TR, Clark TH, Trade Ben J. tenure, and tradition: influence of sociocultural factors on resource use in Melanesia. Conserv Biol 2005;19:1469-77.

[31] Felger RS, Moser MB. People of the Desert and Sea. Ethnobotany of the Seri Indians. Tucson, AZ: University of Arizona Press; 1985.

[32] Basurto X, Ostrom E. Beyond the tragedy of the commons. Economia delle fonti di energia e dell'ambiente (Italian Journal) 2009;52:35-60.

[33] Basurto X. Commercial diving and the Callo de Hacha fishery in Seri Territory. J Southwest 2006;48:189-209.

[34] Diario Oficial de la Federación. 11 de Febrero de 1975. México, DF.; 1975.

[35] Bourillón L. Exclusive fishing zone as a strategy for managing fishery resources by the Seri Indians, Gulf of California, Mexico. Dissertation. Tucson, AZ: University of Arizona at Tucson; 2002.

[36] Basurto X, Coleman E. Institutional and ecological interplay for successful selfgovernance of community-based fisheries. Ecol Econ 2010;69:1094-103.

[37] Basurto X. How locally designed access and use controls can prevent the tragedy of the commons in a Mexican small-scale fishing community. Soc Nat Resour 2005;18:643-59.

[38] Basurto X. Biological and ecological mechanisms supporting marine selfgovernance: the Seri Callo de Hacha fishery in Mexico. Ecol Soc 2008;13.
[39] Torre-Cosío J. Inventory, monitoring and impact assessment of marine biodiversity in the Seri Indian Territory, Gulf of California, México. Dissertation. Tucson, Arizona: University of Arizona; 2002.

[40] Niebla-Larreta JL. Maduración, desove y desarrollo larvario del callo de hacha, Atrina tuberculosa (Sowerby, 1835) bajo condiciones de laboratorio. Hermosillo, Sonora: Universidad de Sonora; 2006.

[41] Angel-Pérez C, Serrano-Guzmán SJ, Ahumada-Sempoal MA. Ciclo reproductivo del molusco Atrina maura (Pterioidea: Pinnidae) en un sistema laguna costero, al sur del pacífico tropical mexicano. Rev de Biol Trop 2007;55:839-52.

[42] Moreno C, Torre J, Bourillón-Moreno L, Durazo M, Weaver AH, Barraza R, et al. Estudio y evaluación de la pesquería de callo de hacha (Atrina tuberculosa) en la región de Bahía de Kino, Sonora y recomendaciones para su manejo. Guaymas Sonora: Comunidad y Biodiversidad; 2005.

[43] Ahumada-Sempoal MA, Serrano-Guzmán SJ, Ruiz-García N. Abundancia estructura poblacional y crecimiento de Atrina maura (Bivalvia: Pinnidae) en una laguna costera tropical del Pacífico mexicano. Rev de Biol Trop 2002;50:1091-100.

[45] Curry G, Koczberski G. The risks and uncertainties of migration: an exploration of recent trends amongst the Wosera Abelam of Papua New Guinea. Oceania 1999;70:130-45.

[46] Koczberski G, Curry GN. Divided communities and contested landscapes: mobility, development and shifting identities in migrant destination sites in Papua New Guinea. Asia Pacific Viewpoint 2004;45:357-71.

[47] Berkes F, Colding J, Folke C. Rediscovery of traditional ecological knowledge as adaptive management. Ecol Appl 2000;10:1251-62.

[48] Hilborn R, Sibert J. Adaptive management of developing fisheries. Mar Policy 1988; $12: 112-21$.

[49] McCook L, Ayling T, Cappo M, Choat JH, Evans RD, De Freitas DM, et al. Adaptive management of the Great Barrier Reef: a globally significant demonstration of the benefits of networks of marine reserves. P Natl Acad Sci USA 2010;43:18278-85.

[50] Fernandes L, Day J, Lewis A, Slegers S, Kerrigan B, Breen D, et al. Establishing representative no-take areas in the Great Barrier Reef: large-scale implementation of theory on marine protected areas. Conserv Biol 2005;19:1733-44.

[51] Wilson J. Matching social and ecological systems in complex ocean fisheries. Ecol Soc 2006;11:9.

[52] Berkes F. Commons in a multi-level world. Int J Commons 2007;2:1-6.

[53] Armitage D. Governance and the commons in a multi-level world. Int J Commons 2008;2:7-32.

[54] Ostrom E, Burger J, Field CB, Norgaard RB, Policansky D. Sustainabilityrevisiting the commons: local lessons, global challenges. Science 1999;284: 278-82.

[55] Berkes F, Hughes TP, Steneck RS, Wilson J, Bellwood DR, Crona BI, et al. Globalization, roving bandits, and marine resources. Science 2006;311:1557-8.

[56] Berkes F. Linkages and multilevel systems for matching governance and ecology: lessons from roving bandits. Bull Mar Sci 2010;86:235-50. 